\title{
Mortality and Causes of Death in Helsinki in 1750-1865 with a Comparison with Tallinn
}

\author{
OIVA TURPEINEN
}

Researcher

\begin{abstract}
Between 1750 and 1865 the population of Helsinki grew from around 1,500 inhabitants to 23,500 inhabitants. Part of this growth is explained by general population growth, typical of both Finland and the rest of Europe. The fact that Helsinki grew more rapidly compared to the other towns of Finland was due to two additional factors with underlying political causes: one was the building of the fortress of Viapori alongside the town at the end of the 1700s and the other Helsinki's becoming the capital of autonomous Finland in 1812. This latter decision moved the administrative and in part the economic focal point of Finland from Turku to Helsinki.

The population growth of Helsinki was not the result of an excess of births over deaths, instead it was caused by migration gain. High mortality, again, was linked to the impact of contagious diseases. Intestinal diseases which spread among children by means of food substances raised infant mortality, in particular, but there were also many other diseases (smallpox, measles, whooping cough, diphtheria, and scarlet fever) which carried many small children to their grave. Cholera, which spread to Helsinki repeatedly in the 1800 s, killed many of Helsinki's inhabitants, but nevertheless cholera's significance has been greatly exaggerated. The most important single killer of the adult population was tuberculosis, but in addition many other diseases, such as typhoid, spotted fever and dysentery, and in part venereal diseases, markedly raised the mortality statistics of Helsinki.

When comparing the remarkably great rises and declines in the annual mortality figures of Helsinki and Tallinn, one notes how very much they coincide. This demonstrates the active contacts existing between the two towns. As a result of the diversity of economic and cultural relations, contagious diseases spread and evolved into epidemics, which rose to great heights in the capitals of both countries, from where they spread to the adjacent regions and other towns. The roads of contagion of Tallinn and Helsinki were partly connected to St. Petersburg, which especially in the 1800 s grew into a metropolis even on a European scale. St. Petersburg had extensive international contacts, which facilitated the spread of diseases to rather remote Northern Europe.
\end{abstract}

Keywords: mortality, causes of death, diseases, population growth, migration gain, historical demography, Helsinki, Tallinn, Baltic Sea Area

\section{Introduction}

This study is a basic survey. It is interesting to study the changes in mortality and causes of death in Helsinki during the period 1750-1865. Although Finland was still in the preindustrial era, development in Helsinki was by no means at a standstill. Helsinki became the capital of Finland when Finland was incorporated into Russia in 1809. For Helsinki this meant monumental construction and growth in many respects. It is possible to make comparisons between Helsinki in the mid-18th century and in the 19th century. Did mortality and causes of death undergo any significant changes during this period and if they did, what factors were behind them? Did mortality in Helsinki differ from the surrounding areas and from that in Finland as a 
whole? (Hornborg 1950, 471 ff.; Waris 1951, 9 ff; Turpeinen 1973a,b, 1977a, and 1982).

In addition to these chronological comparisons, the existing data allows us to make a limited regional analysis. In Helsinki the fortress island of Viapori (Suomenlinna) and its military contingents were registered separately. The data concerning mortality and causes of death in these units can be compared with corresponding data on the population of Helsinki proper (Turpeinen 1984a, 37-51)

Finally, a parallel comparison will be made of mortality and, as far as is possible, the causes of death in Helsinki and Tallinn. This comparison will rely mainly on the studies of Raimo Pullat (Pullat 1976a-d, 1977, 1985, and Pullat-Mereste 1982).

\section{Population development}

After the Great Northern War ended in the 1720s, the population of Helsinki was about 1,000 . By mid-century the population had increased by about 50 percent and totaled nearly 1,500. One hundred years later there were over 15,000 inhabitants in Helsinki. From 1750 to 1850 the population had undergone a tenfold increase (see Appendix table 1). Rapid growth continued, for by 1865 the population of Helsinki was over 23,500.

These figures describe the development of a kind of "basic population". In addition, there were military contingents stationed in Helsinki already in the 18th century, when construction on the Island of Viapori was begun. Also in the 19th century there were many army units stationed in Helsinki. If only population changes were being studied these units could be disregarded. However, as this study also covers demographic changes and because the military contingents were included in the vital statistics registers at that time, these special groups must be included in the study.

This is no small matter. For example, in 1766 the basic population of Helsinki was slightly over 2,000 , but because the military parishes had an additional population of more than 3,300 inhabitants, the total number of inhabitants in Helsinki exceeded 5,300 persons. The previous census in 1763 did not include these military units.

The inclusion of the military contingents in Helsinki's vital statistics also explains the sudden rise in births as well as deaths in Helsinki after 1764. In 1764 there were 94 births and 110 deaths in Helsinki, while the corresponding figures the following year were as high as 163 and 175 (Population and vital statistics tables, the archives of Statistics Finland, TKA; the archives of the Senate's Chamber Expedition, population tables II Dc 1 in the National Archives of Finland, KA).

At the end of the Swedish rule, the ratio of the main population to the military units remained about the same. For example, in 1805 the population of Helsinki was 3,227, but the population of the Island of Viapori including the inhabitants of the fortress totaled 4,606 persons (The population tables of 1805, the archives of Statistics Sweden, Stockholm, partially also from TKA).

During the Russian rule the situation changed, for two reasons. First, the number of military units on Viapori was reduced and, second, Helsinki's becoming the capital of Finland increased the size of the civilian population very rapidly.

However, a few Finnish military units were also formed in Helsinki, of which the Bodyguard and the Naval Contingent were the most important. The population of these units was registered separately. As Viapori also formed a parish of its own, it is feasible to carry out a comparative study.'

\footnotetext{
1 The population and population changes of the parishes of the Bodyguard and the Naval Contingent have been included in the Swedish-Finnish parish until 1840 as well as the German parish founded at the end of the period of study. The Greek-Orthodox congregation has not been included at all in the study.
} 


\section{The population structure}

Because fertility and especially infant mortality were extremely high during the preindustrial period, the age structure of the population usually resembled a pyramid. The sides of the pyramid were gently sloped because there were only a few old age groups. The age structure of the population of Helsinki in 1750-1865 only partially resembles this common type. There were very few elderly people in Helsinki at the end of the 18th century. For example, in 1769 the number of persons over 60 years of age was 74 , in other words 3.6 percent of the population. No noticeable changes were registered in the beginning of the 19th century, for in 1855 the corresponding percentage was about four among the basic Helsinki population. If the military contingents are included, the proportion of "pensioners" grows even smaller (Population tables, TKA).

The remarkably large proportion of small children is consistent with the pyramid model, but these are the only similarities. Especially worth noting is the large proportion of 20-40year-olds. This is natural in military parishes (see Appendix table 2), but this age group is clearly overrepresented also in the basic Helsinki population. This phenomenon is obviously caused by the high mortality in the cities. Urban population growth in the preindustrial era was mainly caused by positive net migration. The in-migrants were men and women in their prime working years, which had an impact on the age structure (Waris 1951, 157; Rosenberg 1966).

It is understandable that this favorable age structure in Helsinki, and cities in general, had many consequences (Turpeinen 1977a, 126-127). The proportion of the working-aged, the breadwinners, was relatively high compared to the children and the aged, the dependents. This should be emphasized especially in the preindustrial era, before the coming of the machine age, when the role of physical labor was essential.

Another question is the impact of the large proportion of fertile age groups on fertility. Wasn't fertility exceptionally high as a result? The answer is not that simple. In 1769 there were 978 persons aged $20-50$ years in Helsinki proper, equaling $48 \%$ of the total population. With the military contingents included, these age groups totaled 3,100 or $62.8 \%$ of the total population.

Furthermore, the ratio of women to men should be taken into consideration. In Helsinki proper the difference was small: in 1769 there were slightly over one thousand persons of both sexes in Helsinki, but in the military parishes the number of men was just under 2,200 and the number of women about 700 (Senate's Chamber Expedition, population tables ).

If we study another cross-sectional period, the year 1855 (see Table 1), the number of women in Helsinki proper slightly exceeded the number of men: in the entire population there were 107 women to every 100 men (Population tables, TKA). In the group under 15 years of age the difference was minimal, however. In the fertile-aged group of 15-49-year-olds, the ratio was 106 women to 100 men. For the group over 50 years of age the ratio was 121 women to 100 men.

The disproportion between the sexes was most striking in the military parishes. For each 100 men in the age group 15-49 years there were only 19 women. The overall ratio here between the sexes was 28 women to 100 men.

The considerable number of soldiers also had an impact on the total sex distribution of the population of Helsinki. The overall ratio between the sexes in the total population of Helsinki was 90 women to 100 men, whereas in the age group 15-49 years there were only 82 women to 100 men.

In answer to the question posed earlier, the high proportion of men did indeed cause higher fertility, but primarily outside marriage. Already at a very early stage Helsinki held a leading position in the number of children born outside marriage (Turpeinen 1981).

\footnotetext{
${ }^{2}$ In the mid-18th century the number of the oldest old people was estimated too high; their year of birth was not always exactly known.
} 
Table 1. The population of Helsinki in 1855 according to sex and age.

\begin{tabular}{|c|c|c|c|c|c|c|}
\hline \multicolumn{7}{|c|}{ Helsinki proper } \\
\hline Age & Men N & $\%$ & Women $\mathrm{N}$ & $\%$ & Total N & Total \% \\
\hline $\begin{array}{r}0-14 \\
15-49 \\
50-\end{array}$ & $\begin{array}{r}2206 \\
4401 \\
753\end{array}$ & $\begin{array}{l}30.0 \\
59.8 \\
10.2\end{array}$ & $\begin{array}{r}2271 \\
4669 \\
912\end{array}$ & $\begin{array}{l}28.9 \\
59.5 \\
11.6\end{array}$ & $\begin{array}{l}4477 \\
9070 \\
1665\end{array}$ & $\begin{array}{l}29.4 \\
59.6 \\
11.0\end{array}$ \\
\hline Total & 7360 & 100.0 & 7852 & 100.0 & 15212 & 100.0 \\
\hline \multicolumn{7}{|c|}{ Military units } \\
\hline Age & Men N & $\%$ & Women $\mathrm{N}$ & $\%$ & Total N & Total \% \\
\hline $\begin{array}{r}0-14 \\
15-49 \\
50-\end{array}$ & $\begin{array}{r}186 \\
1727 \\
21\end{array}$ & $\begin{array}{r}9.6 \\
89.3 \\
1.1\end{array}$ & $\begin{array}{r}182 \\
329 \\
24\end{array}$ & $\begin{array}{r}34.0 \\
61.5 \\
4.5\end{array}$ & $\begin{array}{r}368 \\
2056 \\
45\end{array}$ & $\begin{array}{r}14.9 \\
83.3 \\
1.8\end{array}$ \\
\hline Total & 1934 & 100.0 & 535 & 100.0 & 2469 & 100.0 \\
\hline \multicolumn{7}{|c|}{ The total population of Helsinki } \\
\hline Age & Men N & $\%$ & Women N & $\%$ & Total N & Total \% \\
\hline $\begin{array}{r}0-14 \\
15-49 \\
50-\end{array}$ & $\begin{array}{r}2392 \\
6128 \\
774\end{array}$ & $\begin{array}{r}25.7 \\
65.9 \\
8.4\end{array}$ & $\begin{array}{r}2453 \\
4998 \\
936\end{array}$ & $\begin{array}{l}29.2 \\
59.6 \\
11.2\end{array}$ & $\begin{array}{r}4845 \\
11126 \\
1710\end{array}$ & $\begin{array}{r}27.4 \\
62.9 \\
9.7\end{array}$ \\
\hline Total & 9294 & 100.0 & 8387 & 100.0 & 17681 & 100.0 \\
\hline
\end{tabular}

\section{Fertility and mortality}

In the following fertility as well as mortality in Helsinki will be studied using data from three different periods: 1750-1772, 1808-1809, and 1816-1865 (see Appendix tables 3-5). The time interval for the first period is one year, whereas the second period covering the war of 1808-1809 has been studied in more detail, month by month, because of its exceptionally high mortality. For the third period beginning in 1815 and extending over half a century a five-year interval seemed justified because Heikki Waris has already carried out a year-by-year study on mortality in Helsinki.

Between the years 1750-72 there were 2,558 registered births in Helsinki. The number of deaths during the same period was 2,866 , resulting in a natural population loss of 308 persons. Among this excessive number of deaths, a total of 211 had been registered in $1750-64$. When the total population of Helsinki increased from about 1,500 to 2,300 persons at the same time, the net migration rate was over 1,000 persons. This is remarkably high considering Helsinki's small population.

Examined yearly per 1,000 mean population, the following results were obtained for the period 1750-72: fertility 35.4 per thousand, mortality 39.7 per thousand, and the natural population decrease 4.3 per thousand. Dividing the period into two parts is justified for further analysis: the first one covering the years $1750-64$ and the second one the years $1765-72$. As already mentioned, Helsinki quartered quite an extensive number of military contingents during the second period. The results are shown in Table 2.

Table 2. Birth rate and mortality in Helsinki, 1750-1972.

\begin{tabular}{lcccccc} 
Period & \multicolumn{2}{c}{ Birth rate } & \multicolumn{2}{c}{ Mortality } & \multicolumn{2}{c}{ Difference } \\
& $\mathrm{N}$ & per thousand & $\mathrm{N}$ & per thousand & $\mathrm{N}$ & per thousand \\
$1750-64$ & 1263 & 41.6 & 1474 & 48.6 & -211 & -7.0 \\
$1765-72$ & 1295 & 30.9 & 1392 & 33.2 & -97 & -2.3 \\
$1750-72$ & 2558 & 35.4 & 2866 & 39.7 & -308 & -4.3
\end{tabular}


The most interesting figures here are the numbers indicating a very marked decline both in fertility as well as in mortality after 1764 . The main reason is quite simply that the fertility decline was caused by the rapid increase of soldiers in Helsinki. When simultaneously the number of women of the same age remained unchanged, the result was a reduction in fertility. This was also the main factor for the decline in mortality, although for somewhat different reasons. Because a major portion of mortality at that time was due to the high child and infant mortality, the growing number of soldiers also had a diminishing effect on this type of mortality and on total mortality (See the sources in the Appendix table 3; Turpeinen 1978).

The annual changes in mortality in 1750-72 were extensive - as they generally were in those times. A peak value of 73.1 per thousand was registered in 1762 . Correspondingly, mortality remained below 30 per thousand in many years. In order to analyze the annual fluctuations, it is necessary to examine the causes of death more closely. This will be discussed later in more detail.

If mortality in Helsinki was remarkably high in 1762, high figures were occasionally registered later also. Already in the first year of the war in 1808 mortality was 50.0 and in the second year, 1809 , as high as 81.7 per thousand. During these two years the natural population loss was 262 persons. This was a very large number in a community of less than 4,000 inhabitants.

Appendix table 4 shows the monthly development in mortality in 1808-1809 in Helsinki. Mortality was already remarkably high in the summer of 1808 , but it began a sharp increase in December $1808 .^{3}$ In January some signs of declining mortality were seen, but in February 1809 the mortality of Helsinki increased again considerably. In this respect the darkest period in Helsinki was May and June 1809. In late summer there were still great losses, but a declining tendency finally began before the end of the year (see the sources of Appendix table 4).

Mortality remained very high in Helsinki also during the third period being studied, 181665. During this entire period 27,088 persons were born and 29,803 persons died, so the natural population decrease was 2,715 persons. ${ }^{4}$ Thus the only reason Helsinki grew was positive net migration. Waris has examined the role of migration in the history of Helsinki. He has estimated that during $1816-65$ a total of 51,851 persons migrated to Helsinki whereas 32,900 persons left the city, resulting in a positive net migration rate for this period of 18,951 persons (Waris 1951, 158). These figures show clearly the significance of in-migration for Helsinki as well as the remarkably high mobility of the city population. Annual in-migration during 181665 was as high as 67.1 per thousand and even out-migration was 42.6 per thousand, so the total migration or mobility is 109.7 per thousand. From this we can conclude that altogether 11 percent of the population of Helsinki migrated during this period. ${ }^{5}$

A closer study of fertility and mortality in different parishes of Helsinki shows that in Helsinki proper ${ }^{6}$ fertility and mortality were almost equal during 1816-65 (see Appendix table 5). The number of births was 24,041 and the number of deaths 24,064 persons. The statistics also show that during the second 25 -year-period mortality had a declining tendency. Between $1841-$ 65 - unlike during the period $1816-40$ - fertility exceeded mortality. However, the mortality of the total population of Helsinki did not decline from 1816-40 to 1841-65. The reason was the extremely high mortality in the parishes of Viapori as well in the bodyguard and the naval contingents. The total natural population loss in these three parishes during 1841-65 was 2,203 persons. So although development concerning the basic population of Helsinki was positive the excess of births compared to deaths during 1841-65 was 734 persons - the total natural

\footnotetext{
${ }^{3}$ When the monthly mortality has been calculated for the year 1808 the coefficients 12.62 (February), 12.2 (30-day months), and 11.81 (31-day months) were used. The corresponding coefficients for the year 1809 were 13.04, 12.17, and 11.77 .

${ }^{4}$ According to the study of Waris $(1951,145)$ 28,403 persons were born and 31,143 died in 1816-65; the difference was 2,740 persons. The deviation is due to the fact that Waris had collected data also on Greek-Orthodox persons who are not included in this study.

5 After the Waris' study Rosenberg (1966) has pointed out the great mobility also elsewhere in Uusimaa province.

${ }^{6}$ The concept "Helsinki proper" means almost the same as the Swedish-Finnish parish. In this study, however,

the births and deaths of the parishes of the Bodyguard and the Naval Contingent of couple of years before 1841 have been included as well as the corresponding data of the German parish founded at the end of the era.
} 
population decrease in Helsinki during the second 25-year-period was no less than 1,469 persons (See the sources of Appendix Table 5).

The annual fluctuations in mortality were still extensive. During three years - in 1831 , 1853 , and 1855 - mortality rose over 70 per thousand. Furthermore, it rose over 50 per thousand in 1819,1833 and 1854 . Low values in mortality - less than 30 per thousand - were registered many times in the 1820 s (in 1821, 1823, 1824 and 1827), twice in the 1840 s - in 1844 , and 1845 - and three times at the end of the period (1860, 1863 and 1864) (Waris 1951, 145).

\section{Mortality according to age group}

\section{Infant mortality}

During the preindustrial era infant mortality was an exceptionally significant factor in agespecific mortality. First, infant mortality formed a substantial part of mortality as a whole. Second the short- and long-term fluctuations and changes in infant mortality were closely connected with other factors in the development of a community.

In Finland as a whole, infant mortality was already declining at the end of the 1700 s and in the early 1800 s. In $1751-1800$ infant mortality was 218 , in $1801-1850$ it was 198 , and in $1851-$ 1900 it was down to 165 (Turpeinen 1973b, 1977b, 1979a, 1984b, and 1987b).

How then did infant mortality develop in Helsinki during the years 1750-1865? Was the trend in Helsinki similar to that in other parts of Finland or did it possibly have specific characteristics of its own? The table below indicates that the general development in Helsinki was very much the same as in other parts of Finland (Table 3). Whereas infant mortality in Helsinki during the period $1750-72$ was 342 , during 1816-65 the corresponding figure was 260 (the previous references, and original sources: vital statistics, TKA)

Table 3. Infant mortality in Helsinki, 1750-1752, 1808-1813, and 1816-1865.

$\begin{array}{lcc}\text { Period } & \text { Number of deaths } & \text { Per thousand live births } \\ 1750-1764 & 467 & 370 \\ 1765-1772 & 407 & 314 \\ 1808-1813 & 212 & 253 \\ 1816-1820 & 218 & 205 \\ 1821-1825 & 331 & 243 \\ 1826-1830 & 425 & 246 \\ 1831-1835 & 626 & 273 \\ 1836-1840 & 689 & 246 \\ 1841-1845 & 820 & 259 \\ 1846-1850 & 934 & 282 \\ 1851-1855 & 1114 & 313 \\ 1856-1860 & 837 & 234 \\ 1861-1865 & 1086 & 248 \\ 1750-1772 & 874 & 342 \\ 1816-1840 & 2289 & 248 \\ 1841-1865 & 4791 & 266 \\ 1816-1865 & 7080 & 260\end{array}$

In comparing infant mortality in Helsinki with other parts of Finland one can see that it was much higher in Helsinki. The trend in Helsinki's infant mortality was not a direct decline, either. Table 4 indicates that during $1841-65$ it was higher than during the preceding 25-year period. To find out the reason for this change it is necessary to examine how infant mortality rates vary in different socioeconomic groups. This can be done by studying infant mortality rates among children born in marriage and those born outside marriage. 
Infant mortality among children born outside marriage in Helsinki has been studied more closely for the period 1816-65. This was a rather significant phenomenon at the time, for during this 50-year period about 5,600 children, in other words every fifth child, on the average, was born outside marriage. Furthermore, the proportion of births outside marriage increased at the end of the period. While the proportion of births outside marriage during 1816-40 was 17.7 percent, the corresponding figure for the period $1841-65$ was as high as 22.2 percent. A detailed discussion about the various factors underlying this phenomenon is not possible here, but in addition to the age and sex factors mentioned above, ideological factors, housing problems, and possibilities to build a family, etc. are certainly of importance (Waris 1951).

Table 4 . The number of children born outside marriage and their mortality counted for every five years during 1816-1865.

$1=$ number of extramarital births

2 = proportion of extramarital births of all live births as a percentage

$3=$ number of extramarital children died under the age of one year

$4=$ number of extramarital children died under the age of one year, per 1,000 extramarital live births

$\begin{array}{lcccc}\text { Period } & 1 & 2 & 3 & 4 \\ 1816-20 & 137 & 12.9 & 62 & 453 \\ 1821-25 & 199 & 14.6 & 63 & 317 \\ 1826-30 & 317 & 18.4 & 115 & 363 \\ 1831-35 & 400 & 17.6 & 162 & 405 \\ 1836-40 & 568 & 20.3 & 207 & 364 \\ 1841-45 & 712 & 22.4 & 287 & 403 \\ 1846-50 & 689 & 20.8 & 304 & 441 \\ 1851-55 & 801 & 22.5 & 428 & 534 \\ 1856-60 & 859 & 24.0 & 279 & 325 \\ 1861-65 & 927 & 21.2 & 314 & 339 \\ 1816-40 & 1621 & 17.5 & 609 & 376 \\ 1841-65 & 3988 & 22.2 & 1612 & 404 \\ 1816-65 & 5609 & 20.6 & 2221 & 396\end{array}$

Table 5. Infant mortality among marital children in Helsinki, 1816-1865.

$1=$ number of marital children

2 number of marital children who died under the age of one year

$3=$ infant mortality of marital children

$\begin{array}{lccc}\text { Period } & 1 & 2 & 3 \\ 1816-40 & 7629 & 1680 & 220 \\ 1841-65 & 14014 & 3179 & 227 \\ 1816-65 & 21643 & 4859 & 224\end{array}$

The difference between marital and extramarital children in regard to infant mortality is really marked. One can see that the infant mortality rate of marital children did not undergo much of an increase during the period 1841-65 compared to the preceding period of 1816-40. The infant mortality of extramarital children did increase, however, during this same period from 376 per thousand to 404 per thousand. 
If some sort of a synthesis is to be made on the basis of all factors presented so far, in order to find the causes behind the population phenomena in Helsinki, many different factors, the problem of poverty, the age and sex structure of the population, the increasing number of woman servants, the growing number of extramarital children, and finally the increase in infant mortality can all be linked together.

Even though the importance of economic factors cannot be denied - differences in the standard of living in different groups, for example - it would still be wrong to see infant mortality as purely a consequence of economic factors. The figures presented above on infant mortality over five-year periods raise questions about what could have caused the fluctuations. When the annual fluctuations are examined on the basis of Appendix Tables 6 and 7, it is difficult to imagine that the economic situation could have changed that dramatically. One key background factor is infectious diseases, which are, of course, at least partly connected to economical circumstances. The subject of infectious diseases will be discussed later in relation to causes of death.

\section{Other age groups}

The advanced Finnish population statistics provide a chance to study age-specific mortality as early as in the middle of the 18th century (Turpeinen 1973b, 1977a, 1979b; Turpeinen and Kannisto 1997). In this context the subject will be examined only as part of the cause-of-death studies. Appendix tables 8 and 9 show the number of deaths in different age groups. They already show that mortality is concentrated in distinctly different age groups in different years.

For a view of age-specific mortality and its development in Helsinki, the number of deaths must be compared to the total number of persons in the corresponding age group. This comparison has been carried out for the periods 1750-72, 1808-13, and for eight different years during the period $1816-65$, four of which were years of exceptionally low mortality (1824, 1827,1844 , and 1845) and the other four years of exceptionally high mortality. The age groups have then been combined to get age groups larger than five years. The results are the following:

Table 6. Age-specific mortality in Helsinki, 1750-1855.

Age-specific mortality

$\begin{array}{ccccc}\text { Period } & 0-9 \text { years } & 10-39 \text { years } & 40-59 \text { years } & 60 \text { and older } \\ 1750-72 & 125.2 & 14.4 & 32.7 & 98.3 \\ 1808-13 & 77.2 & 20.4 & 61.0 & 256.9 \\ 1824 & 47.6 & 9.6 & 18.0 & 76.7 \\ 1827 & 53.0 & 17.6 & 27.5 & 105.4 \\ 1831 & 87.5 & 30.9 & 87.8 & 191.4 \\ 1833 & 88.6 & 37.2 & 46.3 & 66.4 \\ 1844 & 55.2 & 12.8 & 21.6 & 56.9 \\ 1845 & 50.8 & 11.6 & 21.6 & 51.2 \\ 1854 & 108.7 & 34.9 & 66.7 & 123.1 \\ 1855 & 120.2 & 39.4 & 75.5 & 183.8\end{array}$

The above figures and Appendix tables 8 and 9 indicate both a remarkably extensive variation between the different age groups and a certain trend of development. The mortality of children ten years old and younger was declining, whereas in older age groups, especially among 10-39-year-olds, mortality was on the rise. Especially in years of exceptionally high mortality, the high mortality was found among persons over 10 years of age. In order to see what is behind this phenomenon, the causes of death must be examined. 


\section{Causes of death}

In addition to examining age-specific mortality, the Finnish material makes it possible to outline the development of the causes of death. It is natural that in studying causes of death all available data sources must be used and that the compatibility of the sources then shows whether or not the statistics are valid.

Concerning Finland as a whole, studies have been made of the causes of annual fluctuations in mortality at the end of Swedish rule. It was found that economic factors such as crop variations cannot sufficiently explain the fluctuations in mortality. The examination must be extended to infectious diseases, which are significant determinants in the rise and decrease of mortality (Turpeinen 1980a).

What about Helsinki? By studying the annual development of mortality during 1750-72 as well as the causes of death (Appendix table 10), one notes that especially smallpox and measles registered at the time as one category - have had an essential impact on these swings. Whooping cough, spotted fever, and dysentery also affected the annual fluctuations. There was also a shadowy "burning disease", probably at least part of which was not only the spotted fever and dysentery mentioned above, but also various kinds of typhoid.

Similar observations can be made for the years 1816-65 (see Appendix table 11). However, one has to remember that smallpox had lost much of its hold by the beginning of the 19 th century because of vaccination. The effects of vaccination can be seen in all of Finland (Turpeinen 1980b; Jutikkala 1984) but especially in Helsinki, where the conditions for carrying out vaccinations were more favorable than in the sparsely populated rural areas. As smallpox waned, mortality among children under ten started to decline. An even stronger impact on the decrease in mortality in this age group was caused by the rather considerable decline in infant mortality at the end of the $1700 \mathrm{~s}$ and the beginning of the $1800 \mathrm{~s}$. This phenomenon can partially be explained by campaigns for breastfeeding, for example (Turpeinen 1987b).

Appendix table 11 shows that in many years whooping-cough, scarlet fever, and measles - the last mentioned was registered separately in 1774 - caused raging epidemics which killed a great many children. At the end of this period diphtheria was also very disastrous. In addition to these diseases which mainly afflicted children, there were other diseases which took their toll especially on the adult population. Dysentery, the close companion of poverty, killed an especially high number of people in 1852. The puzzling "burning fever" and "nerve fever", diseases which probably were typhoid, took many of Helsinki's citizens to their grave during the years $1832-33$ and $1855-56$.

In the 1800 s cholera was a very notorious disease, which intermittently in wide pandemics extended its tentacles to Finland, but mainly only to the largest towns. As already noted, mobility to and from Helsinki was extensive at that time. Thus, the possibilities for cholera and other infectious diseases to spread to Helsinki were excellent. The mortality of adults, especially, increased remarkably during the cholera years - in the beginning of $1830 \mathrm{~s}$, at the end of the $1840 \mathrm{~s}$, and in the $1850 \mathrm{~s}$.

Although cholera was a significant cause of death in certain years, its role should not be overestimated. The main "killer" of adults in Helsinki was tuberculosis. Closer study has been made of this disease with the results shown in Appendix table 12 (population tables, TKA; for whole of Finland, see Backman and Savonen 1934).

First of all, one notices that pulmonary tuberculosis killed much more people in Helsinki than in other parts of the country, on the average (Turpeinen 1973a). In Helsinki pulmonary tuberculosis hit its peak in the mid-1800s. The Appendix table 12 also shows how frighteningly pulmonary tuberculosis raged in Viapori and in the military contingents. Mortality due to pulmonary tuberculosis was even bigger than the entire mortality of the 1990s.

When explaining the great difference in tuberculosis mortality between the ordinary population and the military units, one must consider army housing conditions. Many of the civilians also lived poorly, however, so this fact alone is not enough to explain the difference. In interpreting the phenomenon as a whole, the age structure must also be taken into consideration. Pulmonary tuberculosis is especially dangerous to the population in its prime. This holds true 
especially for the military contingents, where a great number fell prey to tuberculosis. This means that mortality due to tuberculosis must be kept in mind when estimating the development of age-specific mortality. As noted, a marked increase could be seen at the turn of the 18 th and 19 th centuries.

\section{A comparison with Tallinn}

In general town histories dealing with Tallinn there is much data concerning the development of the size of the population, population changes, diseases, epidemics, medical services, etc. Much has also been written about the general demographic approaches related to these features. More detailed information about long-term demographic phenomena can be obtained from the books and articles written by Raimo Pullat (Pullat 1976a-d, 1977, 1985, 1997; Pullat and Mereste 1982; Mereste and Pullat 1979; see also H. Gustavson 1972, 1976). However, very little comparative research exists concerning the demographic situation of Helsinki and Tallinn. ${ }^{7}$

When comparing mortality in Helsinki and Tallinn in the 1700 s, certain similarities can be observed in the annual fluctuations. In 1710 an exceptionally high number of people were killed by the plague in both cities in just a few months. Although the plague never returned to the northern shore of the Gulf of Finland and Helsinki after that, there is evidence that other epidemics raged in both cities at about the same time. Thus mortality increased in both cities in the beginning of the $1740 \mathrm{~s}$. The same occurred in 1754-57, in the beginning of the $1770 \mathrm{~s}$, and at the end of the $1780 \mathrm{~s}$. In the 1750 s one reason for the rise in mortality in Helsinki, at least, was smallpox. This might also have been the case in Tallinn: according to Pullat, "the citizens of Tallinn were continuously being afflicted by poxes" (Pullat 1985,93).

An age-specific comparison of mortality between the two cities shows many similarities. According to Pullat about 54 percent of all persons who died between 1736-1800 in the Puhevaimu parish in Tallinn were under 20 years of age (Pullat 1985, 92). In Helsinki during the period $1750-72$ a total of 2,866 persons died, of whom 1,545 were under 20, which yields the same percentage - 54 percent (Senate's Chamber Expedition II Dc 1, KA).

Pullat also discusses seasonal fluctuations in mortality in Tallinn, mentioning that child mortality often rose during the summer months. In the summer illnesses of the digestive tract were a common cause of death in Tallinn (Pullat 1985, 92). What was the situation in Helsinki? It is interesting to note that during the period $1750-72$ in Helsinki mortality among children younger than 10 years reached its peak in May but was almost as high in July. Monthly mortality was lowest in February (Turpeinen 1978, 530).

These preliminary observations also prove the necessity and usefulness of a comparative study. It would be useful to find more material for comparison about Tallinn in order to be able to answer the following questions, for example:

- the infant mortality rate among marital and extramarital children,

- the importance of pulmonary tuberculosis for mortality as well as for its long-term development in Tallinn,

- pulmonary tuberculosis as a cause of death in different social groups.

It would also be interesting to study the development of mortality due to smallpox: how rapidly did the new protection method spread - first inoculation and then vaccination - and how did it affect mortality from smallpox (in Tallinn and in Helsinki). Further questions would be the impact of other infectious diseases on mortality as well as the differences in living conditions between different social groups and their impact on mortality, etc.

The examples presented here have dealt only with mortality. Comparative data would also be needed on marriage and fertility as well as family history in general.

\footnotetext{
${ }^{7}$ The paper presented by Raimo Pullat at the meeting of Estonian and Finnish historians in Tallinn on October 23, 1989 was in that sense very exceptional. See also Pullat 1997.
} 


\section{Conclusion}

Finland's old medieval towns of Turku, Viipuri, and Porvoo were still clearly larger in the beginning of the 1700 s than the latecomer, Helsinki, which was founded in 1550 . Similarly, the medieval town of Tallinn was quite comparable to Turku, but remained distinctly smaller than Stockholm.

Behind the population growth of Helsinki is the change in major power politics configurations in Northern Europe and in the Baltic Sea area. When Sweden lost Ingria, Estonia, and Southeastern Finland, among other areas, in the Peace of Uusikaupunki in 1721, Tallinn and Viipuri fell under the sphere of Russia, the new rising power. The founding of St. Petersburg in 1704 and its rise as the capital of the Russian Empire forced Sweden to take countermeasures. The situation took a turn for the worse for Stockholm when, under the Peace of Turku in 1743, new territories had to be ceded to Russia from Finland up to the Kymi River.

In this new situation regarding major power politics, the building of Viapori at the end of the 1700 s right alongside Helsinki was quite decisive in quickening the growth of the town's population. While Helsinki had only about 1,500 inhabitants in 1750 , thus making it smaller than Porvoo, the situation had changed completely by 1800 , when the population of Helsinki was 3,000 or about one thousand more than in Porvoo. In addition, Viapori's population was greater than Helsinki's.

The war in 1808-09 ended in the Peace of Hamina, when Finland, up to the Tornio River, was ceded to Russia. In 1812 Helsinki became the capital, to where the central administration and the university were transferred from Turku. The monumental center of Helsinki was built at this time. Workers and domestic servants streamed into the new capital. In 1865 Helsinki had about 23,500 inhabitants and was entirely different from the town of half a century earlier. The population of Helsinki had also exceeded that of Turku, making Helsinki definitely the largest city in Finland.

The development of the population and mortality of Helsinki between 1750 and 1865 coincides with the end of the preindustrial and premedical age. Doctors were almost at a loss in fighting contagious diseases, and the methods of care often led the patient more readily to a rapid death than to a cure. Almost the only field where success was achieved was the smallpox vaccination inaugurated using Jenner's method in the beginning of the 1800s. On the other hand, many other contagious diseases such as tuberculosis, typhoid, spotted fever, dysentery, scarlet fever, measles, cholera, diphtheria, and venereal diseases advanced at their own speed in the urban community and caused great loss. In the growing city the water supply and sewerage also faltered. Wells were polluted when they were infected by disease-spreading microbes, especially in the summertime, increasing infant mortality, in particular. On the other hand, tuberculosis, which raged unleashed and advanced at a constant pace, was particularly deadly for the population of prime working age.

As a whole, the mortality of Helsinki in 1750-1865 was greater than fertility. This means that the growth of Helsinki was entirely the result of migration gain. This situation was typical of cities in the preindustrial age, and the mortality rate was generally in direct proportion to population size. The population of Tallinn, which was about 6,700 in 1763 and about 20,700 in 1858 , grew only as due to migration gain. Almost regularly during this period annual mortality in Tallinn was greater than fertility. In St. Petersburg this same phenomenon was even more pronounced. During the period 1765-1865 the population of St. Petersburg grew from about 150,000 to 540,000 , although there were almost 150,000 more deaths than births at this time. The rapid population growth of St. Petersburg necessitated a migration gain of almost 540,000 persons over the 100-year period mentioned.

The growing city of Helsinki had diverse commercial and cultural contacts also with the other cities of the Baltic Sea area, especially with Tallinn, in addition to St. Petersburg. This can also be seen when comparing epidemics and disease statistics. There is close uniformity in the rises and declines of mortality, because, due to frequent contacts, epidemics often taxed the populations of both Helsinki and Tallinn at about the same time. 


\section{References}

Backman, Woldemar and Severi Savonen. 1934. Keuhkotaudin kulku Suomessa vuosina 1771-1929 (The course of tuberculosis in Finland in 1771 -1929). Helsinki.

Gustavson, H. 1972. Tallinna vanadest apteekidest kuni 1917. Tallinn.

Gustavson, H. 1976. Tervishoid (Health care). In: Tallinna ajologu, 1860-ndate aastateni, edited by Raimo Pullat. Tallinn.

Hornborg, Eirik. 1950. Helsingin kaupungin historia. 2. osa. Ajanjakso 1721-1809 (History of the city of Helsinki. Part 2. From 1721 to 1809$)$. Helsinki.

Jutikkala, Eino. 1984. Spridningsmönstern hos smittkopporna under andra hälften av 1700-talet $i$ Finland. Festskrift til K. Glamann, pp. 213-233. Odense.

Mereste, U. and R. Pullat. 1979. Tallinna elanikkonna kujenemisest 18. Sajandil ja aegridade rekonstrueerimest ajaloolises demograafias (meetrikaraamature andmeil). Eesti NSV Teaduste Akadeemia Toimised 28, No. 4:285303.

Pullat, Raimo. 1976a. Elanikkond (Population). In: Tallinna ajalogu, 1860-ndate aastateni, edited by Raimo Pullat. Tallinn.

Pullat, Raimo. 1976b. Gorodskoje naselenije Estonii (The urban population in Estonia). Tallinn.

Pullat, Raimo. 1976c. Einige aktuelle theoretische und historiographische Fragen der sowjetitschen historischen Demographie. Jahrbuch für Wirtschaftsgeschichte 1976/IV.

Pullat, Raimo. 1976d. Niektore aktualne zagadnenia teorii $i$ historiografii radzieckiej demografii historycznej. Przezeszlosc demograficzna Polski. Matrialy i Studia, No. 9. Warszawa.

Pullat, Raimo. 1977. Istoritsheskaja demografija v SSSR. In: Problemy istoritsheskoj demografii SSSR. Tallinn.

Pullat, Raimo and U. Mereste. 1982. Über die Formierung der Talliner Stadtbevölkerung im 18. Jahrhundert und die Rekonstruktion der Zeitreiben in der geschichtlichen Demographie (anband der Kirchenbucher). Kölner Vortrage und Abhandlungen zur Sozial - und Wirtschaftgeschichte. Heft 34:1-34. Köln.

Pullat, Raimo. 1985. Tallinnan väestön kuolleisuuden rakenteesta ja kausiluonteisuudesta Pühavaimun seurakunnan 1700-luvun kirkonkirjojen perusteella (On the structure and seasonalness of the mortality of the population of Tallinn on basis of the 18 th century church registers of Pühavaimu congregation). Historiallinen Aikakauskirja 83(2):89-96.

Pullat, Raimo. 1997. Die Stadtbevölkerung Estlands im 18. Jahrhundert. Mainz.

Rosenberg, Antti. 1966. Muuttoliike Uudenmaan läänissa esi-industrialistisen kauden lopulla (1821-1880) (Migration in the province of Uusimaa at the end of the preindustrial era (1821-1880). Historiallisia tutkimuksia, No. 70. Helsinki: Suomen Historiallinen Seura.

Turpeinen, Oiva. 1973a. Regional differentials in Finnish mortality rates 1816-1865. The Scandinavian Economic History Review 21(2):145-163.

Turpeinen, Oiva. 1973b. Ikäryhmittäinen kuolleisuus Suomessa 1751-1970 (Age-specific mortality in Finland in 17511970). Helsinki. (Stencil).

Turpeinen, Oiva. 1977a. De finländska städernas folkmängd 1727-1810 (The population in Finnish cities in 17271810). Historisk Tidskrift för Finland 62(2):109-127.

Turpeinen, Oiva. 1977b. Causal relationship between economic factors and mortality. Yearbook of Population Research in Finland 15:31-43.

Turpeinen, Oiva. 1978. Infectious diseases and regional differences in Finnish death rates. Population Studies 32(3):523533.

Turpeinen, Oiva. 1979a. Infant mortality in Finland 1749-1865. The Scandinavian Economic History Review 27(1):121.

Turpeinen, Oiva. 1979b. Fertility and mortality in Finland since 1750. Population Studies 33(1):101-114.

Turpeinen, Oiva. 1980a. Les causes des fluctuations annuelles du taux de mortalité Finlandais entre 1750 et 1806. Annales de Démographie Historique, pp. 287-296. Paris.

Turpeinen, Oiva. 1980b. Die Sterblichkeit an Pocken, Masern und Keuchhusten in Finland in den Jahren 1751 bis 1865. In: Mensch und Gesundheit in der Geschichte, edited by A.E. Imhof. (Abhandlungen zur Geschichte der Medizin und der Naturwissenschaft 39:135-163) Husum.

Turpeinen, Oiva. 1981. Avioton lapsi esiteollisessa Suomessa (An illegitimate child in preindustrial Finland). Kotiseutu (1):12-21.

Turpeinen, Oiva. 1982. The urban population in Finland 1815-1865. Yearbook of Population Research in Finland 20:52-67.

Turpeinen, Oiva. 1984a. Befolkningsförhållanden i Viborgs finska, svenska och tyska församlingar åren 1816-1865 (Conditions of the population in Vyborg's Finnish, Swedish, and German parishes in1816-1865). In: Svenskt $i$ Finland 2: demografiska och socialhistoriska studier, edited by Max Engman and Henrik Stenius, pp. 37-51. Skrifter utgivna av Svenska litteratursallskapet i Finland, No. 519. Helsingfors: Svenska litteratursällskapet i Finland.

Turpeinen, Oiva. 1984b. The percentage of death under one year of age of all deaths in Finland 1749-1865. Yearbook of Population Research in Finland 22:46-59.

Turpeinen, Oiva. 1987a. Katastrofaalinen kuolleisuus Suomen kaupungeissa 1808-1809 (Catastrophic death in Finnish cities in 1808-1809). In: Nälkä, talous, kontrolli, edited by Kari Pitkänen, pp. 127-150. Helsinki: Helsingin yliopiston talous- ja sosiaalihistorian laitos. 
Turpeinen, Oiva. 1987b. Lastensuojelu ja väestönkehitys: lastensuojelun lääkinnöllinen ja sosiaalinen kehitys Suomessa (Child welfare and population development: the medical and social development of child welfare in Finland). In: Suomen lastensuojelun historia by Panu Pulma and Oiva Turpeinen, pp. 270-470. Helsinki: Lastensuojelun Keskusliitto.

Turpeinen, Oiva and Väinö Kannisto. 1997. Abridged life tables for Finland 1751-1880. Population 1997, No. 5. Helsinki: Statistics Finland.

Waris, Heikki. 1951. Helsingin kaupungin historia. 3.osa, 2. Ajanjakso 1809-1875 (History of the city of Helsinki. Part 3. From 1809-1875). Helsinki.

\section{Appendices}

Appendix table 1. The population of Helsinki in 1727-1865.

$\begin{array}{cccc}\text { Year } & \text { Population } & \text { Year } & \text { Population } \\ 1727 & 1170 & 1785 & 2879 \\ 1730 & 1178 & 1790 & 2733 \\ 1733 & 1132 & 1795 & 3103 \\ 1740 & 1314 & 1800 & 3022 \\ 1744 & 1250 & 1805 & 3227 \\ 1747 & 1375 & 1810 & 3554 \\ 1749 & 1507 & 1815 & 4276 \\ 1754 & 1887 & 1820 & 7021 \\ 1757 & 2072 & 1825 & 7925 \\ 1760 & 2330 & 1830 & 10432 \\ 1763 & 2376 & 1835 & 11300 \\ 1766 & 2009 & 1840 & 13313 \\ 1769 & 2136 & 1845 & 15271 \\ 1772 & 2355 & 1850 & 15489 \\ 1775 & 2486 & 1855 & 15212 \\ 1780 & 2527 & 1860 & 18980 \\ & & 1865 & 23438\end{array}$

Note: These numbers do not include the population of Viapori and the population of the military contingents.

Source: Turpeinen 1977b, 124-25; population tables, TKA (Tilastokeskuksen arkisto, The archives of the Statistics Finland). 
60

Appendix table 2. The age structure of the population in Helsinki in 1750, 1769, 1815, and 1855.

$\begin{array}{llll}1750 & 1769 & 1815 & 1855\end{array}$

\begin{tabular}{|c|c|c|c|c|}
\hline \multicolumn{2}{|l|}{ Age group } & \multicolumn{2}{|c|}{ Helsinki proper } & \\
\hline $0-4$ & 160 & 307 & 582 & 2518 \\
\hline $5-9$ & 94 & 117 & 157 & 1046 \\
\hline $10-19$ & 332 & 451 & 521 & 2188 \\
\hline $20-29$ & 314 & 404 & 991 & 3252 \\
\hline $30-39$ & 275 & 354 & 923 & 2897 \\
\hline $40-49$ & 166 & 220 & 672 & 1646 \\
\hline $50-59$ & 82 & 109 & 301 & 1050 \\
\hline $60-69$ & 56 & 57 & 102 & 415 \\
\hline $70-79$ & 29 & 10 & 24 & 195 \\
\hline $80-$ & 12 & 7 & 4 & 5 \\
\hline Total & 1520 & 2036 & 4277 & 15212 \\
\hline \multicolumn{2}{|l|}{ Age group } & \multicolumn{2}{|c|}{ Military contingents, etc. } & \\
\hline $0-4$ & & 218 & 61 & 179 \\
\hline $5-9$ & & 122 & 22 & 122 \\
\hline $10-19$ & & 311 & 44 & 84 \\
\hline $20-29$ & & 888 & 130 & 1132 \\
\hline $30-39$ & & 784 & 130 & 542 \\
\hline $40-49$ & & 450 & 75 & 165 \\
\hline $50-59$ & & 116 & 39 & 38 \\
\hline $60-69$ & & 11 & 18 & 7 \\
\hline $70-79$ & & 2 & 5 & - \\
\hline 80- & & 1 & 1 & \\
\hline Total & & 2903 & 525 & 2269 \\
\hline \multicolumn{2}{|l|}{ Age group } & \multicolumn{2}{|c|}{ Total population of Helsinki } & \\
\hline $0-4$ & & 525 & 643 & 2697 \\
\hline $\begin{array}{l}5-9 \\
10-10\end{array}$ & & 239 & 179 & 1168 \\
\hline $10-19$ & & 762 & 565 & 2272 \\
\hline $20-29$ & & 1292 & 1121 & 4384 \\
\hline $30-39$ & & 1138 & 1053 & 3439 \\
\hline $40-49$ & & 670 & 747 & 1811 \\
\hline $50-59$ & & 225 & 340 & 1088 \\
\hline $60-69$ & & 68 & 120 & 422 \\
\hline $70-79$ & & 12 & 29 & 195 \\
\hline $80-$ & & 8 & 5 & 5 \\
\hline Total & 1520 & 4939 & 4802 & 17481 \\
\hline
\end{tabular}

Source: The archives of the Senate's Chamber Expedition (II Dc 1), KA (Kansallisarkisto, The National Archives of Finland); population tables, TKA. 
Appendix table 3. Annual average population, fertility and mortality in Helsinki in 17501772.

$1=$ average population $\quad 2$ number of births

$3=$ fertility

$4=$ number of deaths

$5=$ mortality

$6=$ difference between number of births and deaths

$7=$ difference between number of births and deaths (per thousand)

$\begin{array}{rrrrrrrr}\text { Year } & 1 & 2 & 3 & 4 & 5 & 6 & 7 \\ 1750 & 1513 & 68 & 44.9 & 55 & 36.4 & 13 & 8.5 \\ 1751 & 1566 & 63 & 40.2 & 46 & 29.4 & 17 & 10.8 \\ 1752 & 1658 & 80 & 48.3 & 98 & 59.1 & -18 & -10.8 \\ 1753 & 1750 & 65 & 37.1 & 77 & 44.0 & -12 & -6.9 \\ 1754 & 1842 & 96 & 52.1 & 83 & 45.1 & 13 & 7.0 \\ 1755 & 1918 & 92 & 48.0 & 86 & 44.8 & 6 & 3.2 \\ 1756 & 1980 & 75 & 37.9 & 133 & 67.2 & -58 & -29.3 \\ 1757 & 2042 & 90 & 44.1 & 113 & 55.3 & -23 & 11.2 \\ 1758 & 2116 & 92 & 43.5 & 67 & 31.7 & 25 & 11.8 \\ 1759 & 2202 & 84 & 38.1 & 68 & 30.9 & 16 & 7.2 \\ 1760 & 2288 & 95 & 41.5 & 101 & 44.1 & -6 & -2.6 \\ 1761 & 2346 & 100 & 42.6 & 119 & 50.7 & -19 & -8.1 \\ 1762 & 2353 & 80 & 34.0 & 172 & 73.1 & -92 & -39.1 \\ 1763 & 2368 & 89 & 37.6 & 146 & 61.7 & -57 & -24.1 \\ 1764 & 2383 & 94 & 39.4 & 110 & 46.2 & -16 & -6.8 \\ 1765 & 5328 & 163 & 30.6 & 135 & 25.3 & 28 & 5.3 \\ 1766 & 5311 & 130 & 24.5 & 192 & 36.2 & -62 & -11.7 \\ 1767 & 5303 & 166 & 31.3 & 150 & 28.3 & 16 & 3.0 \\ 1768 & 5157 & 140 & 27.1 & 149 & 28.9 & -9 & -1.8 \\ 1769 & 5011 & 161 & 32.1 & 158 & 31.5 & 3 & 0.6 \\ 1770 & 5053 & 183 & 36.2 & 172 & 34.0 & 11 & 2.2 \\ 1771 & 5284 & 184 & 34.8 & 178 & 33.7 & 6 & 1.1 \\ 1772 & 5515 & 168 & 30.5 & 258 & 46.8 & -90 & -16.3\end{array}$

Source: The collections of the Genealogical Society of Finland, KA; population and vital statistics tables at the archives of the Senate's Chamber Expedition, KA; microfilms of the archives of the Church, KA; Turpeinen 1977b, 124-25. 
Appendix table 4. Monthly fertility and mortality in Helsinki in 1808-1809.

$1=$ period

$3=$ births

$5=$ deaths

$7=$ difference (between 3 and 5)

$$
\begin{aligned}
& 2=\text { average population } \\
& 4=\text { fertility (per thousand) } \\
& 6=\text { mortality } \\
& 8=\text { difference (between } 4 \text { and } 6 \text { ) }
\end{aligned}
$$

\begin{tabular}{|c|c|c|c|c|c|c|c|c|}
\hline & 1 & 2 & 3 & 4 & 5 & 6 & 7 & 8 \\
\hline Jan & 1808 & 3799 & 10 & 31.1 & 9 & 28.0 & 1 & 3.1 \\
\hline Feb & 1808 & 3800 & 10 & 33.2 & 9 & 29.9 & 1 & 3.3 \\
\hline Mar & 1808 & 3794 & 5 & 15.6 & 17 & 52.9 & -12 & -37.3 \\
\hline Apr & 1808 & 3787 & 7 & 22.6 & 9 & 29.0 & -2 & -6.4 \\
\hline May & 1808 & 3779 & 1 & 3.1 & 15 & 46.9 & -14 & -43.8 \\
\hline Jun & 1808 & 3766 & 7 & 22.7 & 19 & 61.6 & -12 & -38.9 \\
\hline Jul & 1808 & 3759 & 12 & 37.7 & 14 & 44.0 & -2 & -6.3 \\
\hline Aug & 1808 & 3754 & 10 & 31.5 & 19 & 59.8 & -9 & -28.3 \\
\hline Sep & 1808 & 3749 & 12 & 39.0 & 13 & 42.3 & -1 & -3.3 \\
\hline Oct & 1808 & 3748 & 11 & 34.7 & 12 & 37.8 & -1 & 3.1 \\
\hline Nov & 1808 & 3744 & 9 & 29.3 & 16 & 52.1 & -7 & -22.8 \\
\hline Dec & 1808 & 3726 & 9 & 28.5 & 36 & 114.1 & -27 & -85.6 \\
\hline Jan & 1809 & 3710 & 11 & 34.9 & 19 & 60.3 & -8 & -25.4 \\
\hline Feb & 1809 & 3700 & 13 & 45.8 & 26 & 91.6 & -13 & -45.8 \\
\hline Mar & 1809 & 3682 & 8 & 25.6 & 30 & 95.9 & -22 & -70.3 \\
\hline Apr & 1809 & 3659 & 9 & 29.9 & 32 & 106.4 & -23 & -76.5 \\
\hline May & 1809 & 3633 & 12 & 38.9 & 41 & 132.8 & -29 & -93.9 \\
\hline Jun & 1809 & 3603 & 7 & 23.6 & 40 & 135.1 & -33 & -111.5 \\
\hline Jul & 1809 & 3584 & 7 & 23.0 & 24 & 78.8 & -17 & -55.8 \\
\hline Aug & 1809 & 3565 & 8 & 26.4 & 21 & 69.3 & -13 & -42.9 \\
\hline Sep & 1809 & 3553 & 7 & 24.0 & 16 & 54.8 & -9 & -30.8 \\
\hline Oct & 1809 & 3546 & 13 & 43.1 & 18 & 59.7 & -5 & -16.6 \\
\hline Nov & 1809 & 3541 & 11 & 37.8 & 15 & 51.6 & -4 & -13.8 \\
\hline Dec & 1809 & 3539 & 13 & 43.2 & 14 & 46.6 & -1 & -3.4 \\
\hline $\begin{array}{l}\text { Year } \\
\text { Year }\end{array}$ & $\begin{array}{l}808 \\
809\end{array}$ & $\begin{array}{l}\overline{3} \overline{756} \\
3625\end{array}$ & $\begin{array}{l}103 \\
119\end{array}$ & $\begin{array}{l}27.4 \\
32.8\end{array}$ & $\begin{array}{l}188 \\
296\end{array}$ & $\begin{array}{l}50.0 \\
81.7\end{array}$ & $\begin{array}{r}-\overline{-85} \\
-177\end{array}$ & $\begin{array}{l}-22.6 \\
-48.9\end{array}$ \\
\hline 1808 & & 3690 & 222 & 30.1 & 484 & 65.6 & -262 & -35.5 \\
\hline
\end{tabular}

Source: Population and vital statistics tables, TKA; Turpeinen 1987a. 
Appendix table 5. Fertility, mortality and the difference between them in Helsinki for fiveyear periods from 1816 to 1865 .

$1=$ average population

$2=$ births

$3=$ fertility (per thousand)

$4=$ deaths

$5=$ mortality

$6=$ difference (between 2 and 4)

$7=$ difference (between 3 and 5 , per thousand)

Period

1816-20

$1821-25$

$1826-30$

1831-35

$1836-40$

$1841-45$

$1846-50$

$1851-55$

$1856-60$

1861-65

$1816-20$

1821-25

$1826-30$

$1831-35$

$1836-40$

$1841-45$

1846-50

1851-55

1856-60

1861-65

1841-45

1846-50

1851-55

1856-60

1861-65

1841-45

1846-50

1851-55

1856-60

1861-65

1816-20

1821-25

1826-30

1831-35

$1836-40$

1841-45

1846-50

1851-55

1856-60

1861-65
2

$\begin{array}{rr}5647 & 975 \\ 7709 & 1384 \\ 9651 & 1652 \\ 11867 & 2043 \\ 14708 & 2524 \\ 14294 & 2583 \\ 15380 & 2651 \\ 15351 & 2912 \\ 17167 & 3276 \\ 21270 & 4041\end{array}$

667

782

689

$$
889
$$

1545

1655

1385

1021

775

265

1480

1550

906

790

1202

1345

1448

1473

1092

480

$\begin{array}{rr}6316 & 1066 \\ 8491 & 1427 \\ 10340 & 1704 \\ 12756 & 2156 \\ 16253 & 2711 \\ 18774 & 3172 \\ 19763 & 3308 \\ 18751 & 3569 \\ 19824 & 3583 \\ 23217 & 4392\end{array}$

3

Helsinki proper

$34.5 \quad 1092$

$35.9 \quad 1106$

$34.2 \quad 1540$

$34.4 \quad 3100$

$34.3 \quad 2497$

$36.1 \quad 1973$

$34.5 \quad 2927$

$37.9 \quad 4058$

$38.2 \quad 2709$

$38.0 \quad 3062$

Viapori

27.3
11.0
15.1
25.4
24.2
24.9
35.8
51.7
25.3
68.7

238

125

205

149

258

354

464

668

190

84

Bodyguard

$29.9 \quad 331$

$27.0 \quad 473$

38.6

13.2

38.8

307

327

212

Naval contingent

$\begin{array}{rr}24.1 & 275 \\ 27.6 & 334 \\ 29.6 & 499 \\ 28.8 & 219 \\ 11.3 & 27\end{array}$

The entire city of Helsinki

$\begin{array}{ll}33.8 & 1330 \\ 33.6 & 1231 \\ 33.0 & 1745 \\ 33.8 & 3249 \\ 33.4 & 2755 \\ 33.8 & 2933 \\ 33.5 & 4198 \\ 38.1 & 5532 \\ 36.2 & 3445 \\ 37.8 & 3385\end{array}$

42.1

29.0

33.8

50.9

33.9

31.2

42.5

59.0

34.8

29.2
6

7

$-4.2$

7.2

2.3

$-17.8$

0.3

8.5

$-3.6$

$-15.0$

6.6

9.2

979

$-147$

$-44.1$

$-21.0$

$\begin{array}{rr}-153 & -44.4 \\ -36 & -8.1\end{array}$

$\begin{array}{ll}-71 & -9.2\end{array}$

$-148 \quad-17.9$

$-216 \quad-31.2$

$\begin{array}{ll}-404 & -79.2\end{array}$

$\begin{array}{ll}-92 & -23.7\end{array}$

5.3

$-14.8$

$-34.0$

$-29.2$

$-69.6$

3.5

$-16.8$

$-18.5$

$-38.2$

$-11.3$

0.0

$-8.3$

4.6

$\begin{array}{rr}-41 & -0.8 \\ 093 & -17.1\end{array}$

$\begin{array}{ll}-44 & -0.5\end{array}$

$239 \quad 2.6$

$-890 \quad-9.0$

$\begin{array}{ll}-1963 & -20.9\end{array}$

138

1007 


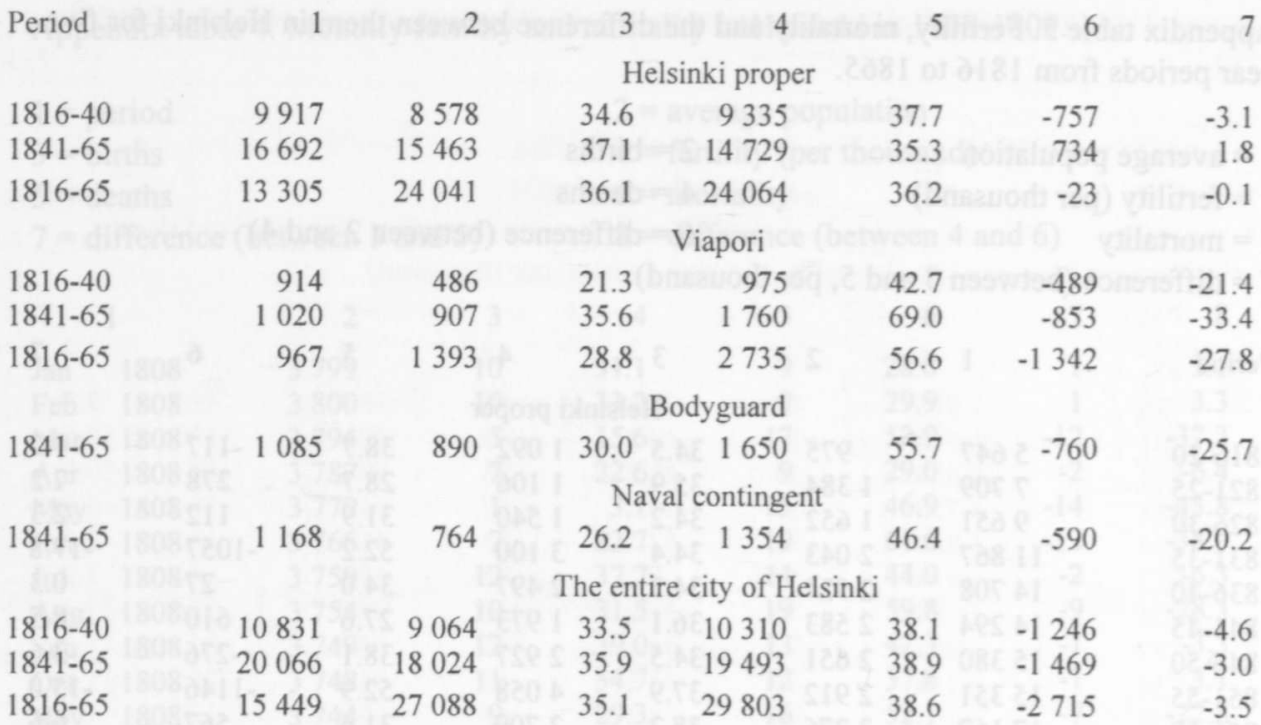

Source: Population and vital statistics tables, TKA.

Appendix table 6. Annual infant mortality in Helsinki in $1816-1865$.

1 = number who died before the age of one year

2 = per thousand live births

$\begin{array}{rrrrrr}\text { Year } & 1 & 2 & \text { Year } & 1 & 2 \\ 1816 & 50 & 234.7 & 1841 & 141 & 255.4 \\ 1817 & 37 & 176.2 & 1842 & 210 & 326.1 \\ 1818 & 44 & 195.6 & 1843 & 182 & 270.8 \\ 1819 & 35 & 172.4 & 1844 & 153 & 233.9 \\ 1820 & 52 & 241.9 & 1845 & 134 & 206.2 \\ 1821 & 49 & 215.8 & 1846 & 201 & 296.0 \\ 1822 & 81 & 304.5 & 1847 & 191 & 307.6 \\ 1823 & 50 & 166.7 & 1848 & 164 & 260.3 \\ 1824 & 56 & 200.7 & 1849 & 154 & 228.5 \\ 1825 & 95 & 323.1 & 1850 & 224 & 318.2 \\ 1826 & 88 & 242.4 & 1851 & 215 & 300.7 \\ 1827 & 62 & 202.0 & 1852 & 234 & 309.5 \\ 1828 & 99 & 300.9 & 1853 & 200 & 283.3 \\ 1829 & 88 & 255.1 & 1854 & 204 & 283.3 \\ 1830 & 88 & 231.0 & 1855 & 261 & 395.5 \\ 1831 & 98 & 273.0 & 1856 & 163 & 247.3 \\ 1832 & 108 & 289.5 & 1857 & 158 & 214.1 \\ 1833 & 133 & 322.0 & 1858 & 177 & 246.9 \\ 1834 & 131 & 283.5 & 1859 & 164 & 214.7 \\ 1835 & 156 & 312.0 & 1860 & 175 & 248.2 \\ 1836 & 99 & 186.8 & 1861 & 211 & 272.6 \\ 1837 & 154 & 295.6 & 1862 & 171 & 201.7 \\ 1838 & 136 & 255.6 & 1863 & 187 & 196.0 \\ 1839 & 148 & 260.1 & 1864 & 223 & 248.1 \\ 1840 & 152 & 264.8 & 1865 & 294 & 324.1\end{array}$

Source: Vital statistics tables, TKA. 
Appendix table 7. Annual infant mortality among extramarital children in Helsinki in 1816 1865 .

$1=$ number of extramarital children

2 = number of children who died before the age of one year

$3=$ proportion extramarital children who died before the age of one year of all extramarital births, per thousand

$\begin{array}{rrrrrrrr}\text { Year } & 1 & 2 & 3 & \text { Year } & 1 & 2 & 3 \\ 1816 & 24 & 7 & 291.7 & 1841 & 126 & 56 & 444.4 \\ 1817 & 34 & 10 & 294.1 & 1842 & 145 & 76 & 524.1 \\ 1818 & 23 & 16 & 695.6 & 1843 & 151 & 56 & 370.9 \\ 1819 & 23 & 11 & 478.3 & 1844 & 143 & 47 & 328.7 \\ 1820 & 33 & 18 & 545.5 & 1845 & 147 & 52 & 353.7 \\ 1821 & 42 & 10 & 238.1 & 1846 & 151 & 68 & 450.3 \\ 1822 & 47 & 15 & 319.1 & 1847 & 119 & 54 & 453.8 \\ 1823 & 42 & 17 & 404.5 & 1848 & 133 & 48 & 360.9 \\ 1824 & 16 & 1 & 62.5 & 1849 & 126 & 54 & 428.6 \\ 1825 & 52 & 20 & 384.6 & 1850 & 160 & 80 & 500.0 \\ 1826 & 67 & 19 & 283.6 & 1851 & 174 & 77 & 442.5 \\ 1827 & 53 & 12 & 226.4 & 1852 & 165 & 69 & 418.2 \\ 1828 & 56 & 24 & 428.6 & 1853 & 168 & 95 & 565.5 \\ 1829 & 57 & 26 & 456.1 & 1854 & 146 & 86 & 589.0 \\ 1830 & 84 & 34 & 404.8 & 1855 & 148 & 101 & 682.4 \\ 1831 & 56 & 33 & 589.3 & 1856 & 197 & 51 & 258.9 \\ 1832 & 82 & 23 & 280.5 & 1857 & 180 & 66 & 366.7 \\ 1833 & 68 & 32 & 470.6 & 1858 & 154 & 56 & 363.6 \\ 1834 & 90 & 36 & 400.0 & 1859 & 164 & 44 & 268.3 \\ 1835 & 104 & 38 & 365.4 & 1860 & 164 & 62 & 378.0 \\ 1836 & 102 & 37 & 362.7 & 1861 & 159 & 52 & 327.0 \\ 1837 & 101 & 32 & 316.8 & 1862 & 160 & 36 & 225.0 \\ 1838 & 133 & 45 & 338.3 & 1863 & 225 & 72 & 320.0 \\ 1839 & 127 & 47 & 370.1 & 1864 & 199 & 68 & 341.7 \\ 1840 & 105 & 46 & 438.1 & 1865 & 184 & 86 & 467.4\end{array}$

Source: Vital statistics tables, TKA 
Appendix table 8. Age-specific deaths in Helsinki in 1750-1772.

$\begin{array}{lrrrrrrrrrrrr}\text { Year } & 0 & 1-2 & 3-4 & 5-9 & 10-19 & 20-29 & 30-39 & 40-49 & 50-59 & 60-69 & 70-79 & 80- \\ 1750 & 12 & 11 & 5 & - & 1 & 8 & 8 & 1 & - & 2 & 5 & 2 \\ 1751 & 17 & 3 & 1 & - & 2 & 2 & 7 & 4 & 4 & 3 & 2 & 1 \\ 1752 & 41 & 11 & 3 & 1 & 2 & 9 & 8 & 10 & 4 & 3 & 5 & 3 \\ 1753 & 20 & 18 & 3 & 1 & - & 5 & 9 & 10 & 6 & 5 & - & - \\ 1754 & 43 & 6 & 3 & - & - & 5 & 6 & 3 & 6 & 5 & 3 & 3 \\ 1755 & 36 & 11 & - & 2 & 4 & 7 & 7 & 4 & 4 & 5 & 5 & 1 \\ 1756 & 32 & 34 & 14 & 5 & 3 & 11 & 14 & 8 & 4 & 4 & 3 & 1 \\ 1757 & 52 & 2 & 2 & 2 & 3 & 11 & 18 & 10 & 9 & 3 & 2 & - \\ 1758 & 17 & 9 & - & - & 2 & 7 & 9 & 8 & 7 & 4 & 2 & 2 \\ 1759 & 40 & 3 & 2 & 1 & 3 & 2 & 6 & 3 & 3 & 4 & 1 & - \\ 1760 & 32 & 13 & 12 & 7 & - & 5 & 16 & 7 & - & 4 & 4 & 1 \\ 1761 & 28 & 21 & 8 & 8 & 3 & 2 & 11 & 15 & 8 & 3 & 8 & 4 \\ 1762 & 30 & 30 & 30 & 18 & 3 & 5 & 12 & 18 & 10 & 10 & 4 & 2 \\ 1763 & 29 & 11 & 14 & 4 & 4 & 15 & 25 & 25 & 6 & 7 & 5 & 1 \\ 1764 & 38 & 13 & 5 & 1 & 2 & 7 & 14 & 12 & 5 & 10 & 2 & 1 \\ 1765 & 47 & 8 & 5 & 2 & 4 & 19 & 22 & 16 & 9 & 2 & - & 1 \\ 1766 & 63 & 50 & 9 & 6 & 8 & 10 & 16 & 10 & 8 & 5 & 4 & 3 \\ 1767 & 40 & 11 & 7 & 6 & 1 & 22 & 25 & 28 & 4 & 2 & 2 & 2 \\ 1768 & 53 & 7 & 2 & 3 & 4 & 15 & 23 & 17 & 11 & 12 & 1 & 1 \\ 1769 & 39 & 25 & 8 & 3 & 3 & 14 & 24 & 19 & 13 & 6 & 2 & 2 \\ 1770 & 55 & 20 & 13 & 5 & 3 & 12 & 10 & 15 & 15 & 10 & 2 & 2 \\ 1771 & 38 & 22 & 4 & 2 & 8 & 30 & 18 & 20 & 13 & 15 & 5 & 3 \\ 1772 & 72 & 24 & 13 & 3 & 2 & 27 & 53 & 35 & 13 & 8 & 4 & 3\end{array}$

Source: The archives of the Senate's Chamber Expedition (II Dc 1); the microfilms of the archives of the Church, KA. 
Appendix table 9. Age-specific deaths in Helsinki in 1816-1865.

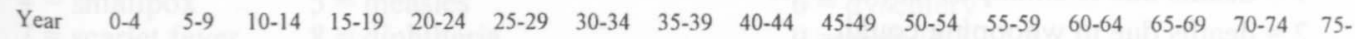

$\begin{array}{lllllllllllllllllll}1816 & 78 & 20 & 3 & 4 & 5 & 15 & 8 & 14 & 11 & 6 & 10 & 11 & 7 & 4 & 5 & 5\end{array}$

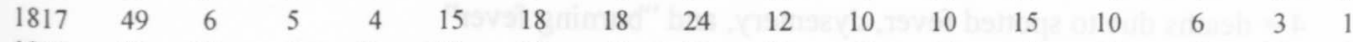

$\begin{array}{lllllllllllllllll}1818 & 75 & 15 & 5 & 11 & 11 & 10 & 11 & 20 & 21 & 15 & 14 & 8 & 11 & 5 & 14 & 1\end{array}$

$\begin{array}{lllllllllllllllll}1819 & 69 & 16 & 6 & 7 & 14 & 20 & 39 & 35 & 24 & 21 & 16 & 16 & 32 & 24 & 6 & 4\end{array}$

$\begin{array}{lllllllllllllllll}1820 & 78 & 10 & 9 & 7 & 12 & 25 & 24 & 22 & 26 & 21 & 17 & 17 & 16 & 6 & 15 & 11\end{array}$

$\begin{array}{lllllllllllllllll}1821 & 79 & 5 & 8 & 3 & 7 & 5 & 13 & 13 & 12 & 8 & 13 & 11 & 6 & 4 & 8 & 2\end{array}$

$\begin{array}{lllllllllllllllll}1822 & 117 & 16 & 3 & 5 & 16 & 8 & 9 & 19 & 17 & 6 & 20 & 11 & 7 & 7 & 4 & 6\end{array}$

$\begin{array}{lllllllllllllllll}1823 & 92 & 8 & 6 & 5 & 13 & 9 & 12 & 12 & 16 & 13 & 16 & 9 & 7 & 8 & 7 & 10\end{array}$

$\begin{array}{lllllllllllllllll}1824 & 93 & 4 & 4 & 5 & 4 & 12 & 16 & 11 & 12 & 12 & 10 & 4 & 8 & 9 & 4 & 3\end{array}$

$\begin{array}{lllllllllllllllll}1825 & 152 & 6 & 1 & 2 & 8 & 14 & 19 & 14 & 14 & 14 & 12 & 7 & 12 & 9 & 6 & 8\end{array}$

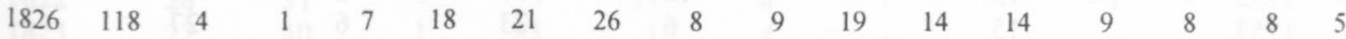

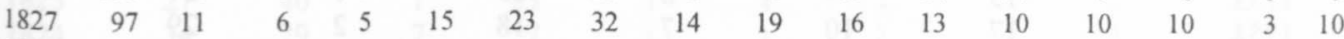

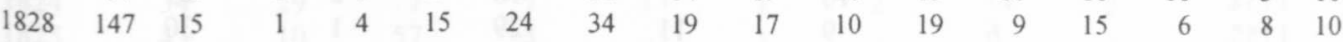

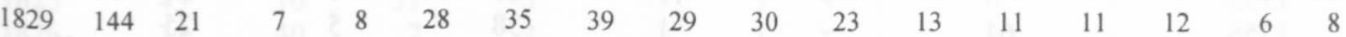

$\begin{array}{lllllllllllllllll}1830 & 136 & 12 & 6 & 12 & 22 & 35 & 27 & 31 & 19 & 15 & 22 & 11 & 10 & 8 & 10 & 11\end{array}$

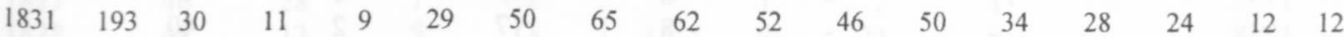

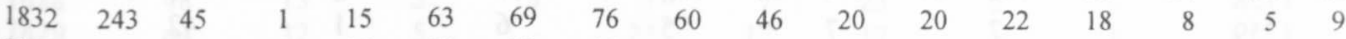

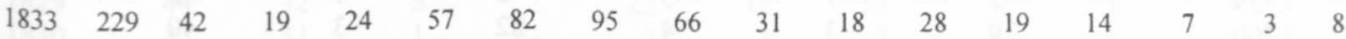

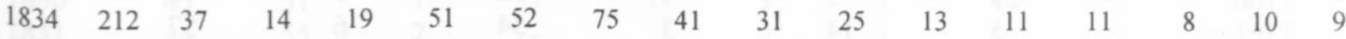

$\begin{array}{lllllllllllllllll}1835 & 234 & 17 & 4 & 8 & 35 & 44 & 46 & 41 & 25 & 12 & 6 & 7 & 7 & 6 & 10 & 5\end{array}$

$\begin{array}{llllllllllllllll}1836 & 179 & 24 & 7 & 15 & 41 & 45 & 55 & 41 & 22 & 12 & 8 & 3 & 7 & 4 & 9\end{array}$

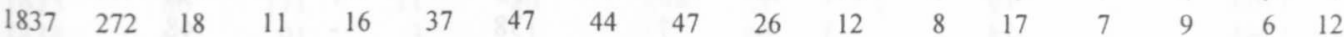

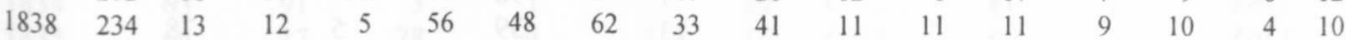

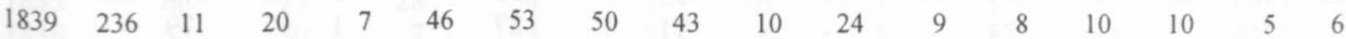

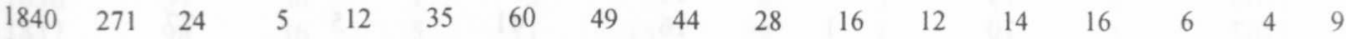

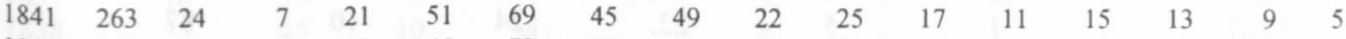

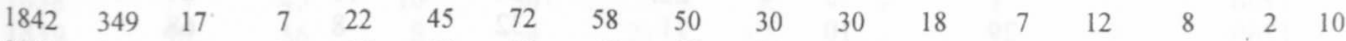

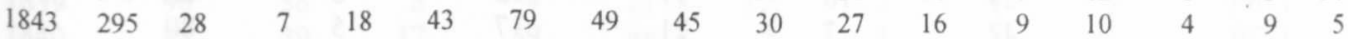

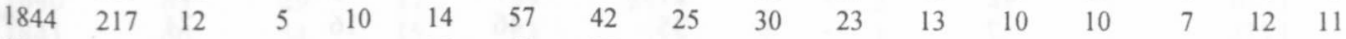

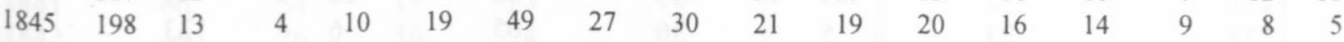

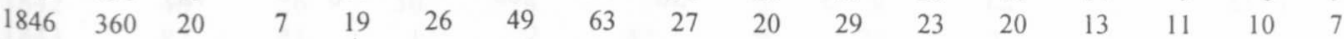

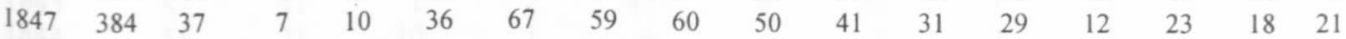

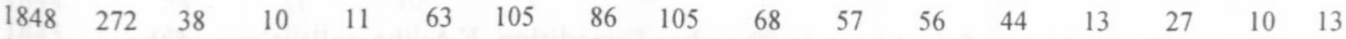

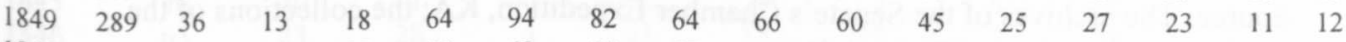

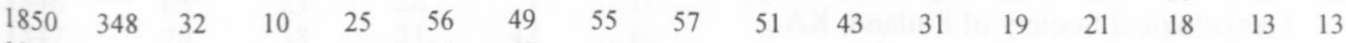

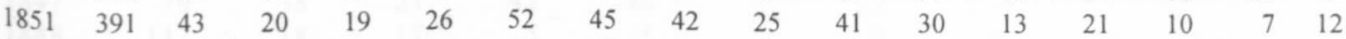

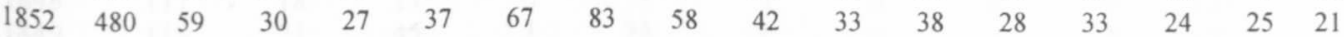

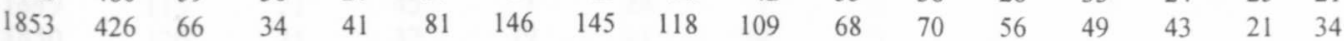

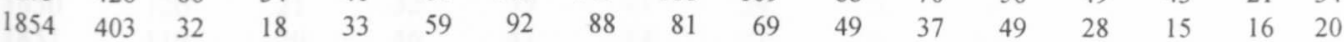

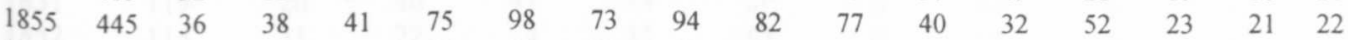

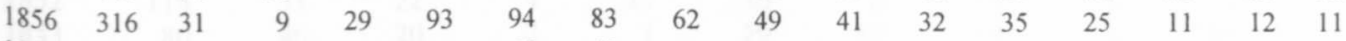

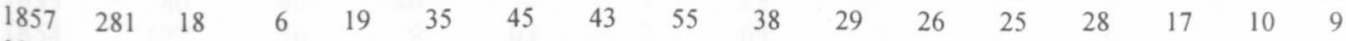

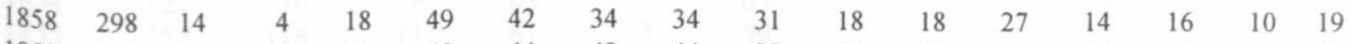

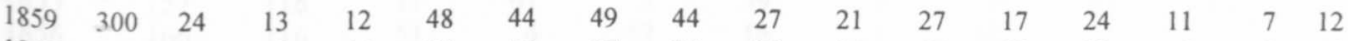

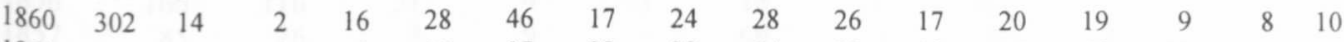

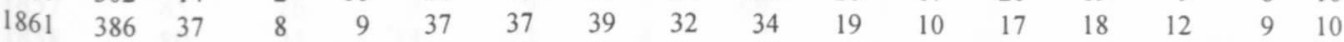

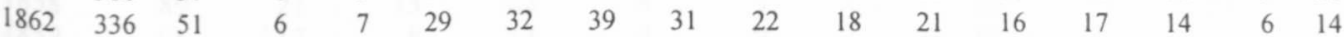

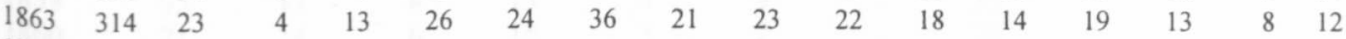

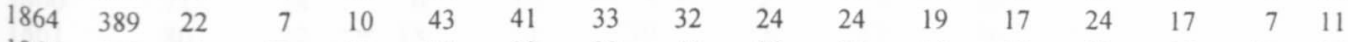

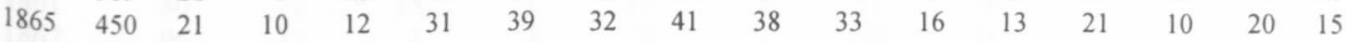

Source: Vital statistics tables, TKA. 
Appendix table 10. Causes of death in Helsinki in 1750-1772.

$1=$ deaths due to smallpox and measles

2 = deaths due to whooping cough

$3=$ deaths due to tuberculosis

4 = deaths due to spotted fever, dysentery, and "burning fever"

$5=$ violent (accidental deaths)

$6=$ other causes of death

\begin{tabular}{rrrrrrr} 
Year & 1 & 2 & 3 & 4 & 5 & 6 \\
\hline 1750 & 3 & 8 & 4 & 7 & 1 & 32 \\
1751 & 7 & - & 6 & 21 & - & 12 \\
1752 & 15 & - & 10 & 19 & 8 & 46 \\
1753 & 15 & - & 6 & 23 & 6 & 27 \\
1754 & 17 & 10 & 7 & 18 & 2 & 29 \\
1755 & 6 & 9 & 11 & 29 & 1 & 30 \\
1756 & 64 & - & 1 & 38 & 5 & 25 \\
1757 & 11 & - & 8 & 49 & 1 & 44 \\
1758 & - & - & 8 & 17 & 2 & 40 \\
1759 & 7 & 7 & 5 & 6 & 1 & 42 \\
1760 & 29 & 3 & 4 & 22 & 3 & 40 \\
1761 & 5 & 14 & 3 & 34 & 6 & 57 \\
1762 & 54 & - & 3 & 48 & 2 & 65 \\
1763 & 19 & - & 20 & 53 & 1 & 53 \\
1764 & 14 & 3 & 7 & 38 & - & 48 \\
1765 & - & - & 13 & 39 & 5 & 78 \\
1766 & 74 & - & 11 & 27 & 1 & 79 \\
1767 & 10 & 1 & 16 & 41 & 5 & 77 \\
1768 & 1 & 5 & 22 & 24 & 10 & 87 \\
1769 & 29 & 10 & 11 & 32 & 8 & 68 \\
1770 & 42 & 7 & 21 & 17 & 5 & 80 \\
1771 & 7 & - & 35 & 46 & 16 & 74 \\
1772 & 23 & 5 & 36 & 65 & 6 & 123
\end{tabular}

Source: The archives of the Senate's Chamber Expedition, KA; the collections of the Genealogical Society of Finland, KA. 
Appendix table 11. Causes of death in Helsinki in 1816-1865. Helsinki proper

$1=$ tuberculosis $\quad 2$ = "burning fever, nerve fever" $3=$ whooping cough

$4=$ smallpox $\quad 5=$ measles $\quad 6=$ dysentery

$7=$ scarlet fever $\quad 8=$ diphtheria $\quad 9=$ syphilis

$10=$ cholera

\begin{tabular}{|c|c|c|c|c|c|c|c|c|c|c|}
\hline Year & 1 & 2 & 3 & 4 & 5 & 6 & 7 & 8 & 9 & 10 \\
\hline 1816 & 18 & 11 & - & 1 & 10 & 5 & - & - & - & - \\
\hline 1817 & 28 & 3 & 5 & 1 & - & 3 & - & - & - & - \\
\hline 1818 & 25 & 5 & 21 & - & 1 & 25 & - & 1 & 2 & - \\
\hline 1819 & 40 & 15 & 3 & - & - & 8 & 3 & - & 1 & - \\
\hline 1820 & 14 & 36 & 2 & 2 & 3 & 4 & 4 & - & - & - \\
\hline 1821 & 24 & 21 & 1 & - & 1 & 3 & 3 & 2 & 1 & 1 \\
\hline 1822 & 28 & 31 & - & - & 27 & 4 & - & - & 1 & - \\
\hline 1823 & 27 & 40 & 1 & 23 & 5 & 4 & - & - & - & - \\
\hline 1824 & 34 & 29 & 7 & 7 & 1 & 1 & 2 & - & 2 & - \\
\hline 1825 & 43 & 10 & 57 & 3 & - & 1 & - & - & - & - \\
\hline 1826 & 31 & 40 & 7 & 2 & - & 1 & - & : & - & - \\
\hline 1827 & 46 & 28 & 7 & 1 & - & 1 & 2 & 1 & - & - \\
\hline 1828 & 48 & 13 & 5 & 3 & 1 & 7 & 23 & 2 & - & - \\
\hline 1829 & 44 & 32 & 5 & - & 22 & 12 & 17 & - & 1 & - \\
\hline 1830 & 43 & 31 & 1 & - & 3 & 1 & 7 & 1 & 1 & - \\
\hline 1831 & 44 & 55 & 2 & 5 & - & 2 & 3 & ; & 3 & 171 \\
\hline 1832 & 87 & 175 & 30 & 53 & 22 & 8 & 1 & 1 & - & - \\
\hline 1833 & 86 & 171 & 11 & 20 & 8 & 53 & 1 & 2 & ; & - \\
\hline 1834 & 63 & 91 & 3 & 1 & 1 & 89 & - & 1 & 1 & - \\
\hline 1835 & 66 & 27 & 28 & 4 & 8 & 16 & 4 & 2 & - & - \\
\hline 1836 & 57 & 50 & 7 & 3 & 7 & 4 & 5 & 1 & 4 & - \\
\hline 1837 & 98 & 36 & 5 & 71 & 15 & 29 & 3 & 3 & 2 & - \\
\hline 1838 & 73 & 45 & 10 & 38 & 3 & 8 & - & 1 & - & - \\
\hline 1839 & 90 & 56 & 8 & 4 & 21 & 17 & - & 1 & 2 & 1 \\
\hline 1840 & 83 & 29 & 17 & 39 & 34 & 2 & 2 & 1 & 1 & - \\
\hline 1841 & 66 & 54 & 15 & 23 & 5 & 3 & 1 & - & - & - \\
\hline 1842 & 46 & 26 & 56 & 4 & 7 & 3 & 8 & - & - & - \\
\hline 1843 & 87 & 41 & 1 & 2 & 47 & 9 & 23 & 3 & 1 & - \\
\hline 1844 & 54 & 21 & 10 & 1 & 4 & - & 3 & 2 & 1 & - \\
\hline 1845 & 46 & 20 & 1 & i & 2 & $\overline{-}$ & 3 & 8 & 2 & - \\
\hline 1846 & 63 & 23 & 28 & 1 & 13 & 15 & 13 & 2 & 4 & - \\
\hline 1847 & 79 & 38 & 23 & 42 & 40 & 5 & 27 & - & 3 & - \\
\hline 1848 & 117 & 18 & 17 & 5 & 5 & - & 8 & 6 & 6 & 120 \\
\hline 1849 & 113 & 21 & 45 & 1 & 28 & 1 & 6 & 3 & 3 & 157 \\
\hline 1850 & 120 & 21 & 32 & 39 & 11 & 29 & 2 & 6 & 3 & - \\
\hline 1851 & 119 & 20 & 46 & 41 & 14 & 21 & 6 & 10 & 6 & - \\
\hline 1852 & 114 & 31 & 22 & 4 & 15 & 230 & 8 & 15 & 3 & - \\
\hline 1853 & 80 & 40 & 20 & 2 & 1 & 29 & 17 & 27 & 5 & 585 \\
\hline 1854 & 127 & 36 & 9 & 63 & 5 & 63 & 3 & 9 & 6 & 122 \\
\hline 1855 & 157 & 118 & 11 & 61 & 3 & 59 & 1 & 7 & 11 & 13 \\
\hline 1856 & 166 & 116 & 51 & 4 & 12 & 16 & 1 & 13 & - & - \\
\hline 1857 & 85 & 26 & 3 & 9 & - & 69 & - & 6 & 2 & 12 \\
\hline 1858 & 89 & 21 & 13 & 22 & 4 & 7 & - & 10 & 1 & 28 \\
\hline 1859 & 95 & 17 & 8 & 13 & 4 & 9 & - & 37 & - & 34 \\
\hline 1860 & 71 & 14 & 6 & 15 & 3 & 2 & - & 28 & - & - \\
\hline 1861 & 80 & 22 & 18 & 1 & 39 & 3 & 13 & 36 & - & - \\
\hline 1862 & 96 & 12 & 1 & 3 & 9 & - & 59 & 56 & - & - \\
\hline 1863 & 93 & 57 & 26 & 1 & - & 16 & 10 & 24 & - & - \\
\hline 1864 & 118 & 43 & 76 & 4 & 22 & 41 & - & 47 & - & - \\
\hline 1865 & 104 & 92 & 53 & 55 & 31 & 26 & - & 46 & 1 & \\
\hline
\end{tabular}

Source: Vital statistics tables, TKA. 
Appendix table 12. Mortality due to tuberculosis in Helsinki in 1816 - 1865.

$1=$ deaths due to tuberculosis in Helsinki proper

$2=$ mortality due to tuberculosis in Helsinki proper

$3=$ deaths due to tuberculosis in Viapori

$4=$ mortality due to tuberculosis in Viapori

$5=$ deaths due to tuberculosis in the Bodyguard

$6=$ mortality due to tuberculosis in the Bodyguard

7 = deaths due to tuberculosis in the Naval Contingent

$8=$ mortality due to tuberculosis in the Naval Contingent

$9=$ deaths due to tuberculosis in Helsinki as a whole

$10=$ mortality due to tuberculosis in Helsinki as a whole

Mortality $=$ per thousand mean population

\begin{tabular}{lrrrrrr} 
Period & 1 & 2 & 3 & 4 & 5 & 6 \\
\hline $1816-20$ & 125 & 4.4 & 34 & 10.2 & - & - \\
$1821-25$ & 155 & 4.0 & 45 & 11.5 & - & - \\
$1826-30$ & 212 & 4.4 & 63 & 18.3 & - & - \\
$1831-35$ & 346 & 5.8 & 37 & 8.3 & - & - \\
$1836-40$ & 401 & 5.5 & 65 & 8.4 & - & 11.5 \\
$1841-45$ & 299 & 4.2 & 121 & 14.6 & 85 & 12.1 \\
$1846-50$ & 492 & 6.4 & 123 & 17.8 & 94 & 11.9 \\
$1851-55$ & 597 & 7.8 & 102 & 20.0 & 54 & 13.4 \\
$1856-60$ & 506 & 5.9 & 32 & 5.9 & 53 & 5.7 \\
$1861-65$ & 491 & 4.6 & 17 & 7.1 & 34 & - \\
$1816-40$ & 1239 & 5.0 & 244 & 10.7 & - & 10.8 \\
$1841-65$ & 2385 & 5.7 & 395 & 15.5 & 320 & - \\
$1816-65$ & 3624 & 5.4 & 639 & 13.2 & - &
\end{tabular}

\begin{tabular}{lrrrr} 
Period & 7 & 8 & 9 & 10 \\
\hline $1816-20$ & - & - & 159 & 5.0 \\
$1821-25$ & - & - & 200 & 4.7 \\
$1826-30$ & - & - & 275 & 5.3 \\
$1831-35$ & - & - & 383 & 6.0 \\
$1836-40$ & - & - & 466 & 5.7 \\
$1841-45$ & 88 & 13.1 & 593 & 6.3 \\
$1846-50$ & 111 & 15.3 & 820 & 8.3 \\
$1851-55$ & 110 & 14.9 & 863 & 9.2 \\
$1856-60$ & 52 & 9.5 & 643 & 6.5 \\
$1861-65$ & 8 & 3.3 & 550 & 4.7 \\
$1816-40$ & - & - & 1483 & 5.5 \\
$1841-65$ & 369 & 12.6 & 3469 & 6.9 \\
$1816-65$ & - & - & 4938 & 6.4
\end{tabular}

Source: Population and vital statistics tables, TKA. 